\title{
FACTORS INFLUENCING OVERALl SERVICE QUALITY OF ONLINE BANKING: A COMPARATIVE STUDY OF Indian PUblic ANd PRIVATe Sector BankS
}

\author{
VIRAL BHATT*, BHOOMI MEHTA**
}

\begin{abstract}
Customer relationship and retention is the key to success for banks. One of the way to achieve it, is through improvement in overall service quality of online banking. This paper have identified factors influencing overall service quality of online banking by survey of 1014 online banking users and have proposed a model. Next, model was validated through a comparative study of public and private sector banks in India. Paper concludes that all independent factors of proposed model do influence overall service quality of online banking of both types of banks but the individual factor influence differently with different bank types.
\end{abstract}

Keywords: online banking, overall service quality, factor analysis, multiple regression analysis, public and private banks.

JEL Classification: $G 21, C 21, O 33, L 86$

\section{INTRODUCTION}

In year 1965, mechanized banking which enabled the balance check and updating at teller counters through centralized computers was introduced in Indian banking system. Gradually the computers were used for reconciliation of transactions in the bank branches in 1980s (K., 2010).

Online banking was introduced in India in late 1990s. (Srivastava). In online banking customers can process different banking transactions like opening a bank

\footnotetext{
* Dr. Viral Bhatt, Director, SAL Institute of Management, Opp. Science city, Sola Bhadaj

Road, Ahmedabad, Gujarat-380060, e-mail: viral.bhatt@sal.edu.in

** Dr. Bhoomi Mehta (Corresponding Author), Assistant Professor, Institute of

Management, Nirma University, Sarkhej - Gandhinagar Highway, Gota, Ahmedabad,

Gujarat 382481, e-mail: bhoomi@nirmauni.ac.in
} 
account, transfer of funds to different accounts, bill payments etc. without physically visiting the bank (Paul \& Richmond, 2007). The online banking transactions can be carried out anywhere and at any time by connecting devices such as desktop, laptop, mobile, tab with the internet. As customers could able to carry out banking activities without going to bank and also at any given point of time, this service very beneficial to them (Tina, 2003).

Another revolution that boosted the usage of online banking services was introduction of mobile phones. In year 1995, mobile phones were introduced in Indian market. Gradually, with the decrease in mobile tariffs of internet plan and the launch of smartphones, internet users through mobile phones increased. (C.Mathapati \& Vidyavati, 2018). Internet users in India are over 560 million and by 2021 it will increase to 600 million. Further, it was found that majority of the Indians accessed the internet through their smartphones (Statista Research Department, 2020). Because of these changes, the usage of online banking also visualised huge growth. An article published in the economic times reported that $51 \%$ of Indian bank customers used online banking channels (Economic Times, 2017).

The gradual upgradation of technology in banks have changed the way conventional banking used to operate. With time there are changes in terms of demographic and social trends. All these have led Indian banking industry to become customer centric. Indian banks have become more customer focused and service oriented (Giannakoudi, 1999) (Byers \& Lederer, 2001).

\section{THE COMPETITIVE LANDSCAPE IN INDIAN BANKING}

Indian banking sector has been witnessing changes since past few years. Various technological and financial innovations like Automated Teller Machines, Credit and Debit Cards, online banking etc. have wholly transformed the façade of Indian banking. These changes along with challenges have also created opportunities for the banks (Kaur \& Rajneesh, 2014).

Banking transactions have become easy and convenient and are better serving to the customers in modern banking era (K., 2010). Technological developments have assisted banks through improved tracking, different service delivery channels and quick query resolutions (S.Suriyamurthi, Mahalakshmi, \& Arivazhagan, 2013). Currently, providing real time information to the customers has become inevitable for the banks to remain competitive (Bhasin, 2007). The focus of banks now is to increase/maintain the market the share by switching to customer centric business model. This could be achieved through customer relationship management (Flavián, Torres, \& Guinalíu, 2004) (Gan, Clemes, 
Limsombunchai, \& Weng, 2006). Both public and private sector banks in India have therefore started services based on innovative technology to better serve its customers. The evaluation of both these types of banks indicate that the strength of private sector banks are online services of bill payment and online shopping, customer communication and technical efficiency while that of public sector banks are accessibility and privacy of online banking and its demonstration at counter. And the weakness that needs to be improved are online services of transaction alerts, online trading and advertisement (Jani, 2012). Thus, there is a need for the banks to continuously increase customers' satisfaction and one of the way to achieve that is through the improvement in overall service quality of online banking. Further it has to be understand that whether the type of banks has any impact on customer's perception of overall service quality of online banking.

\section{Customers' Preferences for Service Quality}

Customer satisfaction and customer retention especially for online banking were highly critical for success of any bank (Abdullah, Manaf, Yusuf, Ahsan, \& Azam, 2014). Customer satisfaction survey would not have much impact on the technicality of the financial products of the banks as they do not have noticeable differences among different banks. Thus the customers were more affected in the functional quality of the financial products as compared to the technical quality (Ülengin, 1998).

To evaluate customer satisfaction of the service quality of online banking, (Saha \& Zhao, 2005) identified nine dimensions such as privacy, personalization, efficiency, fulfilment, reliability, communication, responsiveness, technology update and logistic/technical equipment. A study on the customer satisfaction in Bangladesh was done considering empathy, reliability, assurance, tangibles and responsiveness as factors of service quality of internet banking (Nupur, 2010). Few researchers also did comparative analysis of types of bank with respect to customer satisfaction of online banking for example, (Vanniarajan \& Anbazhagan, 2007) did this comparison by applying SERVEPERF scale.

The research on banking customer satisfaction have considered empathy, responsiveness, assurance, competence, reliability and tangibility as the factors for evaluation service quality. The customer's perception about the services and the actual services indicate the gap. But this is very subjective. Customer satisfaction increases with the higher level of perception over expected service quality and vice versa that is, customer satisfaction decreases with the lower level of perception over expected service quality (Jain \& Gupta, 2004). 
Most customer satisfaction studies conducted so far have emphasised on either offline services or one or two services of digital banking or are conceptual which lack validation. Again, customer satisfaction not necessarily leads to loyalty and similarly customer dissatisfaction does not always lead to customer switching. Therefore it is required to understand the multidimensional constructs of service quality and its implications (Matos, Henrique, \& Rosa, 2013).

\section{BANKing Services EVAluation Models}

(Davis, 1989) The Technology Acceptance Model (TAM) was developed in 1989 and considered attitude and usefulness for adoption decision and ease of use. Later, (Gounaris \& Koritos, 2008) found that the TAM does not consider the individual psychological and social view about acceptance of technology. Further the model also do not consider the demographic factor which impact on the use of technology. (Lian \& Lin, 2008) Perceived cost, perceived reliability and selfefficacy were considered to overcome the limitation of TAM.

(Venkatesh, Morris, Davis, \& Davis, 2003) The Unified Theory of acceptance and use of technology (UTAUT) model combined the models of TPB and TAM and considered social cognitive models and motivational models. Next, (Venkatesh, Thong, \& Xu, 2012) the UTAUT2 model was proposed by extending UTAUT model and considering three new constructs namely hedonic motivation, price value and habit and by doing this the variance explained was substantially increased as compared to original model. Further UTAUT2 model was extended by adding constructs for trust, security and privacy through a cross cultural study (Mohamed Merhia, 2019) (Ali Abdallah Alalwan, 2017).

A conceptual model was suggested through case studies of Iran top e-banks considering the effects of using CRM system in the adoption of m-banking on customer satisfaction and interaction (Hamidi \& Safareeyeh, 2019). Customer satisfaction could not be the only parameter to measure the quality of online banking and therefore a study conducted in China evaluated the effects of experience considering six antecedents to customer satisfaction namely ease of use, design, speed, security, information content and customer support service (Yoon \& Cheolho, 2010).

One of the study focused on discontinuous usage of mobile banking through adoption of Trait Hierarchical Model (THM) and Optimum Stimulation Level Theory (OSLT) (Philip Avornyoa, 2019). A study was conducted in Ghana to ascertain the determinants of internet banking adoption intentions using the social cognitive theory (Boateng, Adam, Okoe, \& Anning-Dorson, 2016). Saudi Arabia's 
m-banking users were studied and proposed a conceptual model combining two models namely UTAUT2 and the D\&M IS Success Model (Baabdullaha, Alalwanb, Ranac, Kizgin, \& Patil, 2019). A revised and extended model was proposed based on UTAUT and TAM to understand the determinants affecting behavioural intentions to adopt mobile banking among generation Y (Waranpong Boonsiritomachai, 2017).

\section{OBJECTIVES OF THE STUDY}

As can be seen from the studies conducted so far, the models have been suggested for different aspect of banking like retail banking, digital banking and mobile banking and that too by considering only few features/services. Moreover, most studies have considered dependent variable such as customer satisfaction, retention or experience for the success of banking. This creates an opportunity to evaluate other aspects that are necessary for the banks to achieve success like customers' overall experience of service quality especially of online banking. Again, the geographic location considered for these studies do not include India. Next, the constructs used by model were proposed considering the macro and micro economic factors of the selected geographical location and many of the studies were conceptual and so they had not validated the model. Considering all these, this paper proposes and validates the model that measures the overall service quality of online banking of Indian Banks. Based on the above literature review, the following research objectives were framed:

- To measure the impact of various factors on overall service quality of online banking.

- To compare the overall service quality of public and private sector banks of India

\section{RESEARCH METHODOLOGY}

6.1. Research design: To understand the impact of various factors of digital banking services on the overall service quality and derive unique solutions, data was collected in different geographical regions, demographic profiles and was analyzed through different tools and techniques. Therefore descriptive crosssectional research design was chosen to perform this study.

6.2. Data collection: Data collection was done using primary as well as secondary data sources. Secondary data sources such as journal articles and websites were referred. Primary data collection was done through self-administered structured questionnaire. 
6.3. Questionnaire design: Questionnaire consisted of twenty-four questions in which first ten questions were related to demographic information and the next six questions were related to banks and online banking information. The last eight questions included a total of forty-four statements with seven point Linkert scale. Among the eight questions, seven were related to independent factors that influence online banking service quality namely assistance (seven statements), competence (six statements), ease of use (seven statements), connectivity (five statements), tangibility (four statements), security (three statements) and accessibility (three statements) and the last was dependent factor related to overall service quality (nine statements).

6.4. Sampling design: For the survey of respondents, certain criteria were identified to ensure the quality of responses. These criteria were related to respondent's minimum age (20 years), minimum time (at least six months) of usage of online banking services of either public (State Bank of India, Bank of Baroda, Punjab National Bank and Bank of India) or private (Housing Development Finance Corporation Bank, Industrial Credit and Investment Corporation of India Bank, Axis Bank and Kotak Mahindra Bank) sector banks. Therefore, to achieve this specific criteria, non-probability sampling design was applied to conduct the extensive research on e-banking services.

The respondents were selected from Gujarat state of India as this state represents the population from entire India. Further, in Gujarat state, four major districts were identified namely Ahmedabad, Baroda, Rajkot and Surat and data was collected from these four districts.

Data was collected from the survey of 1050 respondents and out of that 24 questionnaire were incomplete and so the final sample size came to 1026 respondents. Out of these, 12 outliers were identified by Mahalanobis distance and were removed. Among the final sample size of 1014 respondents, 590 and 424 respondents were digital banking users of private and public sector banks respectively.

6.5. Analytical tools and techniques: SPSS 25 software was used to perform the statistical analysis to identify factors and measure the impact. The exploratory factor analysis was performed to understand the influencing factors with respect to online banking service quality. The multiple regression method was performed to measure the impact of independent variables on overall service quality of public and private sector banks. While performing the analysis, the important factors for examining the data like reliability, convergent validity, and adequacy of sample size were considered. It was also examined that the assumption of the important 
parameters like autocorrelations, multicollinearity, normality and homoscedasticity were not violated.

\section{HYPOTHESES FOR MODEL DEVELOPMENT}

H1. There is significant difference in perceived assistance with respect to overall service quality of digital banking services

H2. There is significant difference in perceived competence and with respect to overall service quality of digital banking services

H3. There is no significant difference in perceived ease of use with respect to overall service quality of digital banking services

H4. There is significant difference in perceived connectivity with respect to overall service quality of digital banking services

H5. There is significant difference between in perceived tangibility with respect to overall service quality of digital banking services

H6. There is significant difference in perceived security with respect to overall service quality of digital banking services

H7. There is significant difference in perceived accessibility with respect to overall service quality of digital banking services

\section{EMPIRICAl ANALYSIS AND Findings}

The most important aspect of quantitative analysis is to understand which factors are influencing to digital banking service quality, therefore factor analysis was performed. To identify the independent factors, KMO and Bartlett's test was performed. This test of sphericity, as shown in the below table, indicate the value of 0.920 which suggest that there are more than two independent factors that are influencing to digital banking services. The KMO and Bartlett value of 0.920 is greater than 0.70 which indicated that adequate samples were selected in the data collection.

Table 1: KMO and Bartlett's Test

Kaiser-Meyer-Olkin Measure of Sampling Adequacy. .920

\begin{tabular}{llr}
\hline Bartlett's Test of Sphericity & Approx. Chi-Square & 20671.228 \\
\cline { 2 - 3 } & Df & 595 \\
\cline { 2 - 3 } & Sig. & .000 \\
\hline
\end{tabular}

Further, communalities extraction of all the thirty-five statements were found to be more than 0.30 and were acceptable in comparison with the benchmark values. The highest communalities extraction was 0.818 while the lowest communalities extraction was 0.478 . 
Table 2: Exploratory Factor Analysis

\begin{tabular}{|c|c|c|c|c|c|}
\hline Factors & Item & $\begin{array}{l}\text { Factor } \\
\text { Loading }\end{array}$ & $\begin{array}{l}\text { Eigen } \\
\text { values }\end{array}$ & $\begin{array}{c}\% \text { of } \\
\text { variance } \\
\text { explained }\end{array}$ & $\begin{array}{c}\text { Reliability } \\
\text { Cronbach } \\
\text { Alpha } \\
\end{array}$ \\
\hline \multirow[t]{7}{*}{ Assistance } & $\begin{array}{c}\text { Easy change of security } \\
\text { questions }\end{array}$ & .809 & \multirow[t]{7}{*}{12.237} & \multirow[t]{7}{*}{34.964} & \multirow[t]{7}{*}{.841} \\
\hline & $\begin{array}{l}\text { Quick issue of debit/credit card } \\
\text { in case of damage/lost }\end{array}$ & .806 & & & \\
\hline & $\begin{array}{l}\text { Proper support in-case of } \\
\text { transaction error }\end{array}$ & .790 & & & \\
\hline & $\begin{array}{l}\text { On-line re-generation/change of } \\
\text { password }\end{array}$ & .744 & & & \\
\hline & $\begin{array}{l}\text { Convey of OTP through phone } \\
\text { call in-case of non-receipt } \\
\text { through SMS }\end{array}$ & .657 & & & \\
\hline & $\begin{array}{c}\text { Reasonability of charges on } \\
\text { digital services offered }\end{array}$ & .579 & & & \\
\hline & Updating on real time basis & .520 & & & \\
\hline \multirow[t]{6}{*}{ Competence } & $\begin{array}{c}\text { Continuity of account login } \\
\text { while transaction execution }\end{array}$ & .851 & \multirow[t]{6}{*}{3.310} & \multirow[t]{6}{*}{8.942} & \multirow[t]{6}{*}{.851} \\
\hline & $\begin{array}{l}\text { Error-free processing of } \\
\text { transactions }\end{array}$ & .776 & & & \\
\hline & Accuracy of account information & .739 & & & \\
\hline & Immediate receipt of OTP & .665 & & & \\
\hline & Quick processing of transactions & .600 & & & \\
\hline & Quick login into account & .433 & & & \\
\hline \multirow[t]{7}{*}{ Ease of use } & $\begin{array}{l}\text { Availability of voice instructions } \\
\text { for visually impaired }\end{array}$ & .868 & \multirow[t]{7}{*}{1.876} & \multirow[t]{7}{*}{5.361} & \multirow[t]{7}{*}{.864} \\
\hline & $\begin{array}{cc}\text { Account/ } & \text { transaction } \\
\text { information are intelligible }\end{array}$ & .821 & & & \\
\hline & $\begin{array}{l}\text { System populates automatic } \\
\text { information }\end{array}$ & .790 & & & \\
\hline & $\begin{array}{l}\text { Images/icons related to type of } \\
\text { transactions }\end{array}$ & .772 & & & \\
\hline & $\begin{array}{l}\text { Minimum steps for transaction } \\
\text { execution }\end{array}$ & .647 & & & \\
\hline & $\begin{array}{l}\text { Clear instructions to execute } \\
\text { transactions }\end{array}$ & .569 & & & \\
\hline & $\begin{array}{ccr}\begin{array}{c}\text { Continuation } \\
\text { connectivity } \\
\text { transaction }\end{array} & \text { of } & \begin{array}{r}\text { server } \\
\text { during }\end{array} \\
\end{array}$ & .496 & & & \\
\hline \multirow[t]{4}{*}{ Connectivity } & $\begin{array}{rrr}\begin{array}{r}\text { Continuous } \\
\text { internet }\end{array} & \text { availability of } \\
\end{array}$ & .846 & \multirow[t]{4}{*}{1.484} & \multirow[t]{4}{*}{4.241} & \multirow[t]{4}{*}{.829} \\
\hline & $\begin{array}{l}\text { Connectivity is constant during } \\
\text { transaction }\end{array}$ & .801 & & & \\
\hline & $\begin{array}{lr}\text { Continuous working } & \text { of } \\
\text { site/application } & \text { while } \\
\text { transaction processing } & \\
\end{array}$ & .751 & & & \\
\hline & $\begin{array}{l}\text { Account accessibility with low } \\
\text { internet connectivity }\end{array}$ & .481 & & & \\
\hline
\end{tabular}




\begin{tabular}{|c|c|c|c|c|c|}
\hline Factors & Item & $\begin{array}{l}\text { Factor } \\
\text { Loading }\end{array}$ & $\begin{array}{l}\text { Eigen } \\
\text { values }\end{array}$ & $\begin{array}{c}\% \text { of } \\
\text { variance } \\
\text { explained }\end{array}$ & $\begin{array}{l}\text { Reliability } \\
\text { Cronbach } \\
\text { Alpha }\end{array}$ \\
\hline & $\begin{array}{l}\text { Availability of server response } \\
\text { during transactions }\end{array}$ & .429 & & & \\
\hline \multirow[t]{4}{*}{ Tangibility } & Exhaustive information & .864 & \multirow[t]{4}{*}{1.275} & \multirow[t]{4}{*}{3.641} & \multirow[t]{4}{*}{.821} \\
\hline & Relevant information & .862 & & & \\
\hline & Understandable information & .831 & & & \\
\hline & $\begin{array}{c}\text { Availability of all banking } \\
\text { services on digital platform }\end{array}$ & .607 & & & \\
\hline \multirow[t]{3}{*}{ Security } & $\begin{array}{l}\text { Sufficient measures taken to } \\
\text { make } \\
\text { secure/safe }\end{array}$ & .896 & \multirow[t]{3}{*}{1.178} & \multirow[t]{3}{*}{3.365} & \multirow[t]{3}{*}{.731} \\
\hline & $\begin{array}{l}\text { Automatically logging off in } \\
\text { case of connectivity loss or } \\
\text { during idleness of account }\end{array}$ & .809 & & & \\
\hline & $\begin{array}{l}\text { Multilevel authorization to } \\
\text { access account }\end{array}$ & .717 & & & \\
\hline \multirow[t]{3}{*}{ Accessibility } & $\begin{array}{l}\text { Availability of digital banking } \\
\text { payment option at merchant/ } \\
\text { service provider }\end{array}$ & .996 & \multirow[t]{3}{*}{1.119} & \multirow[t]{3}{*}{3.197} & \multirow[t]{3}{*}{.793} \\
\hline & $\begin{array}{c}\text { Availability of digital banking } \\
\text { channels whenever required }\end{array}$ & .775 & & & \\
\hline & Compatible for all devices & .508 & & & \\
\hline
\end{tabular}

As indicated in the above table, there are seven independent factors that are influencing to digital banking service quality, derived from pattern matrix. First factor with seven statements was related to perceived assistance (PAS) lies between 0.809 and 0.520 which is significantly high scores. The Eigen value of PAS is 12.237 which is very high and this particular factor explains $34.964 \%$ of variance with respect to overall service quality. The reliability test of the factor, PAS shows the value of Cronbach alpha of 0.841 which shows that all seven statements significantly contribute to this factor.

Second factor amongst the seven is perceived competence (PCT) included six statements. Factor loading of these statements lies between 0.851 and 0.433 which indicate significantly accepted scores except the last statement. The Eigen value of PCT is 3.310 and individually $8.942 \%$ variance explained to overall digital banking' service quality. The Cronbach alpha of PCT is 0.851 and all the six statements significantly contribute to the PCT with respect of overall digital banking service quality.

Third influencing factor is perceived ease of using content (PEOU) with seven statements. The factor loading are from 0.868 to 0.496 which are acceptable score for this factor except for last statement. The Eigen value is 1.876 and this explain $5.361 \%$ of variation and cumulative $49.26 \%$ of variance is explained by the 
first three factors. The Cronbach alpha of PEOU is 0.864 which is significantly higher than the benchmark value.

Fourth influencing factor is perceived connectivity (PCN) with five independent statements. The factor loading of these statements are from 0.846 to 0.429. Except the last statement, factor loading are significantly high and acceptable. The Eigen value of the PCN is 1.48 and explains $4.24 \%$ of variance. The Cronbach alpha is 0.829 , higher than 0.70 which is desirable benchmark value.

Fifth factor identified through the tool principal component analysis is perceived tangibility (PTA) includes four independent statements having factor loading between 0.864 and 0.607 which is significantly high. The Eigen value is 1.28 , higher than 1. PTA contributes to $3.64 \%$ to explain variance and Cronbach alpha of four significantly contributed statements is 0.821 which is desirable.

The sixth factor identified is perceived security (PSC). It included three independent statements and the factor loading are 0.896, 0.809 and 0.717 indicate significantly very high acceptable values. The Eigen value of PSC is 1.18 and 3.37 percentage of variance is explained by this factor. The Cronbach alpha of PSC is 0.731 , which is higher than the benchmark value of reliability.

The last and the important independent factor of digital banking service quality is perceived accessibility (PAC) including three statements. The factor loadings of component $0.966,0.75$ and 0.508 are fairly large and acceptable. The Eigen value of the factor is 1.12 which is more than 1. PAC explains 3.20 percentage of variance and Cronbach alpha is 0.793 , fairly acceptable.

In all, seven factors were identified which influenced the overall service quality of digital banking service. These factors are perceived assurance (PAS), competence (PCT), ease of using (PEOU), connectivity (PCN), tangibility (PTA), security (PSC) and accessibility (PAC). The Eigen value of all these seven factors are more than 1 and Cronbach alpha are more than 0.70 which is more than desirable. All seven variables together explains 63.71 percentage of variance. Overall average variance explained by these factors, except $\mathrm{PCN}$ is more than 0.50 . This indicates that the assumption of convergent validity has not been violated. In the fourth factor which is PCN, the last statement with factor loading 0.429 has been removed and after that the last statement explains 0.523 average variance which is more than 0.50 . It suggests that the assumption of convergent validity has not been violated. 


\section{Online Banking Overall Service Quality Proposed Model}

Based on the results of exploratory factor analysis, the model was constructed considering the measurement of online banking overall service quality. The model assumes that the perceived overall service quality (POSQ) of online banking services was dependent on online banking users' perceived assistance (PAS), perceived competence (PCT), perceived ease of use (PEOU), perceived connectivity (PCN), perceived tangibility (PTA), perceived security (PST) and perceived accessibility (PAC). Based on this assumption, dependent variable POSQ was influenced by seven independent factors as shown in the figure below:

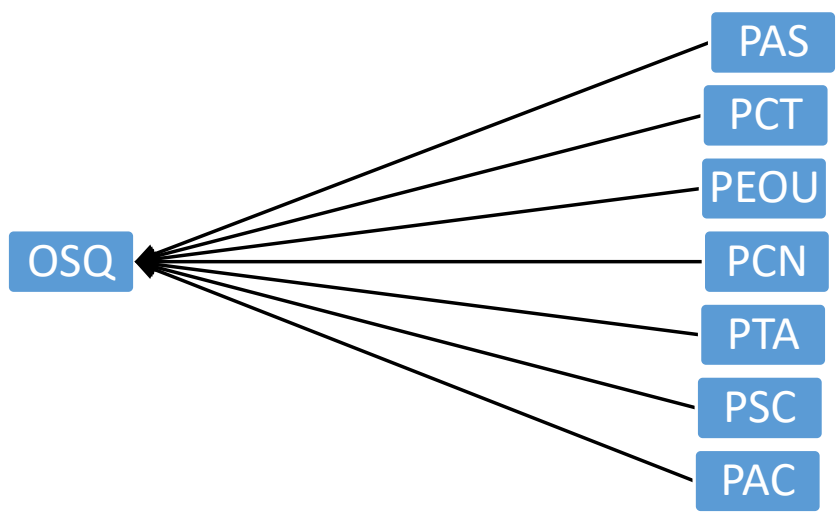

Figure 1: Online banking overall service quality measurement model

The next section includes hypotheses for mode validation followed by findings of multiple regression analysis.

\section{Model VALIDATION: HyPOTHESES}

H8. The independent factors of digital banking service significantly create impact of overall service quality of public and private sector banks.

H9. Perceived assistance create significant impact on overall service quality of digital banking of public and private sector banks.

H10. Perceived competence create significant impact on overall service quality of digital banking of public and private sector banks.

H11. Perceived ease of use create significant impact on overall service quality of digital banking of public and private sector banks.

H12. Perceived connectivity create significant impact on overall service quality of digital banking of public and private sector banks.

H13. Perceived security create significant impact on overall service quality of digital banking of public and private sector banks. 
H14. Perceived accessibility create significant impact on overall service quality of digital banking of public and private sector banks.

H15. Perceived tangibility create significant impact on overall service quality of digital banking of public and private sector banks.

\section{Model VAlidation: AnAlysis AND FindingS}

Table 3: Comparative descriptive statistics and Independent sample T-test

\begin{tabular}{|c|c|c|c|c|c|c|c|c|c|}
\hline \multirow{2}{*}{ Factors } & \multicolumn{3}{|c|}{ Private sector banks } & \multicolumn{3}{|c|}{ Public sector banks } & \multirow[b]{2}{*}{$\begin{array}{c}\text { T- } \\
\text { st } \\
\text { at } \\
\text {. }\end{array}$} & \multirow[t]{2}{*}{ Sig. } & \multirow{2}{*}{$\begin{array}{c}\text { Alternate } \\
\text { Hypothesis } \\
\text { Decision }\end{array}$} \\
\hline & $\mathbf{N}$ & Mean & $\begin{array}{r}\text { Std. } \\
\text { D } \\
\text { e } \\
\text { v. }\end{array}$ & $\mathbf{N}$ & Mean & $\begin{array}{r}\text { Std. } \\
\text { D } \\
\text { e } \\
\text { v. }\end{array}$ & & & \\
\hline PAS & 590 & 4.10 & 1.16 & 424 & 3.65 & 0.93 & -5.53 & 0.00 & Accepted \\
\hline PCT & 590 & 5.67 & 0.80 & 424 & 5.15 & 0.89 & -4.20 & 0.00 & Accepted \\
\hline PEOU & 590 & 4.73 & 0.92 & 424 & 4.19 & 0.86 & -5.68 & 0.00 & Accepted \\
\hline $\mathrm{PCN}$ & 590 & 4.28 & 1.13 & 424 & 3.99 & 1.04 & -4.06 & 0.00 & Accepted \\
\hline PSC & 590 & 4.64 & 1.10 & 424 & 4.34 & 1.11 & -4.25 & 0.00 & Accepted \\
\hline PTA & 590 & 4.84 & 0.98 & 424 & 4.58 & 0.95 & -4.26 & 0.00 & Accepted \\
\hline PAC & 590 & 4.88 & 0.80 & 424 & 4.69 & 0.74 & -3.94 & 0.00 & Accepted \\
\hline POSQ & 590 & 4.52 & 0.86 & 424 & 4.24 & 0.75 & -5.38 & 0.00 & Accepted \\
\hline
\end{tabular}

Based on the exploratory factor analysis and with the support of the literature review, a measurement model for evaluating digital banking service quality was developed. Seven independent factors namely perceived assistance, perceived competence, perceived ease of using, perceived connectivity, perceived tangibility, perceived security and perceived accessibility were identified that influenced perceived overall service quality. Next, comparison of public and private sector banks was done using above parameters. Along with descriptive analysis, independent T-test and multiple regression was performed to analyze and compare the digital banking service quality of public and private sector banks.

As seen from the above table, the mean of private sector banks is significantly higher than public sector banks. All the $t$ values are showing negative sign and significance 0.00 which is less than 0.05 . This indicate that private sector banks provide significantly efficient services than public service banks. Both public and private sector banks have very competence digital banking service quality model and indicate very high perceived value of mean. Even perceived competence, perceived tangibility and accessibility is also having very high value of average with respect to average values and the standard deviations in the responses. Perceived assurance and perceived overall service quality are the most 
important aspects and shows significant difference between public and private sector banks. Private sector banks mean scales significantly higher than public sector banks mean scores. Majority of respondents are more concern regarding security and assurance aspects of digital banking service quality. Their responses are highly fluctuating. Overall all the parameters of digital banking service quality, private banks provide better services than public sector banks in India.

The impact of all the independent factors on overall service quality was measured through multiple regression enter method to validate the model for digital banking service quality model for public and private sector banks in India.

Table 4: Model Summary

\begin{tabular}{|l|l|l|l|l|l|l|l|}
\hline Banks & $\mathrm{R}$ & $\mathrm{R}^{2}$ & $\begin{array}{c}\text { Adjusted } \\
\mathrm{R}^{2}\end{array}$ & $\begin{array}{c}\text { S.E. of } \\
\text { estim } \\
\text { ate }\end{array}$ & F change & Sig. & $\begin{array}{c}\text { Durbin } \\
\text { Wats } \\
\text { on }\end{array}$ \\
\hline Private & 0.928 & 0.861 & 0.859 & 0.2715 & 430.88 & 0.00 & 1.467 \\
\hline Public & 0.817 & 0.667 & 0.651 & 0.3403 & 510.73 & 0.00 & 1.545 \\
\hline
\end{tabular}

Both types of banks shows the strong relationship between all Independent factors and overall service quality. Private sector banks $\mathrm{R}$ value which is 0.928 is significantly higher than the public sector banks. Coefficient of determination indicate that in private sector banks, 86.10 percentage of changes related to overall service quality because of all independent factors. In public sector banks, these seven factors found responsible for 66.70 percentage of changes in overall service quality. The significant value for private and public sector respectively indicate sig 0.00 , F 430.88 and sig. 0.00, F 510.73. Thus all the seven independent factors together create impact on overall service quality of public and private sector banks.

Table 5: Model of private sector banks

\begin{tabular}{|l|c|c|c|c|c|c|c|}
\hline Factor & $\begin{array}{c}\text { Un Std. } \\
\text { Beta }\end{array}$ & $\begin{array}{c}\text { Std. } \\
\text { Beta }\end{array}$ & $\mathbf{t}$ & Sig. & tolerance & VIF & $\begin{array}{c}\text { Alternate } \\
\text { Hypothesis } \\
\text { Decision }\end{array}$ \\
\hline Constant & 0.211 & - & 2.189 & 0.029 & - & - & - \\
\hline PAS & 0.332 & 0.418 & 18.48 & 0.00 & 0.653 & 1.533 & Accepted \\
\hline PCT & 0.154 & 0.186 & 7.170 & 0.00 & 0.495 & 2.019 & Accepted \\
\hline PEOU & 0.100 & 0.114 & 4.264 & 0.00 & 0.467 & 2.139 & Accepted \\
\hline PCN & 0.216 & 0.290 & 12.196 & 0.00 & 0.589 & 1.698 & Accepted \\
\hline PSC & 0.112 & 0.202 & 9.246 & 0.00 & 0.700 & 1.429 & Accepted \\
\hline PAC & 0.092 & 0.086 & 1.506 & 0.01 & 0.590 & 1.695 & Accepted \\
\hline PTA & 0.132 & 0.125 & 2.132 & 0.00 & 0.325 & 3.078 & Accepted \\
\hline
\end{tabular}


Table 6: Model of public sector banks

\begin{tabular}{|l|c|c|c|c|c|c|c|}
\hline \multicolumn{1}{|c|}{ Factor } & $\begin{array}{c}\text { Un Std. } \\
\text { Beta }\end{array}$ & $\begin{array}{c}\text { Std. } \\
\text { Beta }\end{array}$ & $\mathbf{t}$ & Sig. & tolerance & VIF & $\begin{array}{c}\text { Alternate } \\
\text { Hypothesis } \\
\text { Decision }\end{array}$ \\
\hline Constant & 0.295 & - & 2.634 & 0.009 & - & - & - \\
\hline PAS & 0.359 & 0.488 & 20.597 & 0.000 & 0.488 & 2.049 & Accepted \\
\hline PCT & 0.081 & 0.072 & 2.886 & 0.004 & 0.435 & 2.300 & Accepted \\
\hline PEOU & 0.065 & 0.065 & 2.296 & 0.022 & 0.342 & 2.922 & Accepted \\
\hline PCN & 0.206 & 0.248 & 10.301 & 0.000 & 0.475 & 2.107 & Accepted \\
\hline PSC & 0.119 & 0.168 & 7.834 & 0.000 & 0.595 & 1.680 & Accepted \\
\hline PAC & 0.105 & 0.101 & 4.663 & 0.000 & 0.588 & 1.700 & Accepted \\
\hline PTA & 0.092 & 0.105 & 3.815 & 0.001 & 0.338 & 2.958 & Accepted \\
\hline
\end{tabular}

If we compare two models as in above tables, the significance value for all the independent factors related to digital banking services in public and private sector banks are less than 0.05 which indicate that all the variables are significantly contribute to overall service quality. The most influential factor in public and private sector banks is of perceived assurance and second is perceived connectivity. In the private sector banks, perceived competence is third influential factor while in public sector banks it is perceived security. Perceived ease of use, perceived accessibility and perceived tangibility significantly contribute to overall service quality but least contribute to dependent variables. Digital banking service quality model for public and private sector banks, in general, would be as under:

$\mathrm{Y}=\mathrm{a}+\beta 01\left(\mathrm{X}_{1}\right)+\beta 02\left(\mathrm{X}_{2}\right)+\beta 03\left(\mathrm{X}_{3}\right)+\beta 04\left(\mathrm{X}_{4}\right)+\beta 05\left(\mathrm{X}_{5}\right)+\beta 06\left(\mathrm{X}_{6}\right)+$ $\beta 07\left(\mathrm{X}_{7}\right)+\mathrm{e}$

Based on the results of the study, the above model for private sector banks is a under:

$\mathrm{OSQ}=0.211+0.332(\mathrm{PAS})+0.154(\mathrm{PCT})+0.100(\mathrm{PEOU})+0.216(\mathrm{PCN})+$ $0.112(\mathrm{PSC})+0.092(\mathrm{PAC})+0.132(\mathrm{PTA})+\mathrm{e}$

As can be seen from above equation, 10 units of perceived assurance create 3.32 units impact on overall service quality of digital banking. Likewise, 10 units of perceived competence, perceived ease of use, perceived connectivity, perceived security, perceived accessibility and perceived tangibility creates 1.54, 1.00, 2.16, $1.12,0.92,1.32$ units impact respectively on overall service quality of digital banking.

Similarly, the model for public sector banks based on the data analysis, is as under:

$\mathrm{OSQ}=0.295+0.359(\mathrm{PAS})+0.081(\mathrm{PCT})+0.065(\mathrm{PEOU})+0.206(\mathrm{PCN})+$ $0.119(\mathrm{PSC})+0.105(\mathrm{PAC})+0.092(\mathrm{PTA})+\mathrm{e}$ 
As the above equation indicates, 10 units of perceived assurance, perceived competence, perceived ease of use, perceived connectivity, perceived security, perceived accessibility and perceived tangibility creates $3.59,0.81,0.65,2.06,1.19$, 1.95 and 0.92 units impact respectively on overall service quality of digital banking.

Considering the high values of the correlation coefficient with respect to all the independent and dependent variables in both public and private sector banks model, the test of multicollinearity was applied. As can be seen in table no. 5 and 6 , the value of tolerance was more than 0.20 and the value of variance influence factors (VIF) was less than 5 for all the independent variables. This indicate that the assumption of multicollinearity was not violated. Further, various chart related to linearity, normality and homoscedasticity included in Appendix indicate that they were not violated and validate the model of digital banking service quality with respect to public and private sector banks.

\section{CONCLUSION}

Both the research objectives were achieved through this study. The exploratory factor analysis showed the impact of individual factors on overall service quality of online banking. Based on this findings, a model was developed that mentioned the independent factors that influence the overall service quality of online banking namely assistance, competence, ease of use, connectivity, tangibility, security, and accessibility. To further validate the model and to compare the public and private sector banks, multiple regression analysis was applied. Through the findings, the model was validated and the comparison showed that the impact of individual factor will vary in different types of bank.

\section{Limitations OF THE STUDY AND FUTURE RESEARCH}

The study considered respondents who were using online banking for a year and more as these customers could able to justify the responses as they have experience of using online banking. The perception of new users could be different and so the future study could be done on identifying service quality factors of new customers.

The study has validated the model considering public and private sector banks as they have the larger market share. Future study could be conducted considering other types of banks such as foreign banks, co-operative banks and regional rural banks. 
The research findings and conclusion was carried out considering Indian banks and Indian populations. Future study could be done considering other countries banks and populations.

\section{REFERENCES}

1. Abdullah, M. A., Manaf, N. H., Yusuf, M.-B. O., Ahsan, K., \& Azam, S. M. (2014). Determinants of Customer Satisfaction on Retail Banks in New Zealand: An Empirical Analysis Using Structural Equation Modeling. Global Economy and Finance Journal , 63-82.

2. Ali Abdallah Alalwan, Y. K. (2017). Factors influencing adoption of mobile banking by Jordanian bank customers: Extending UTAUT2 with trust. International Journal of Information Management, 99-110.

3. Baabdullaha, A. M., Alalwanb, A. A., Ranac, c. P., Kizgin, H., \& Patil, P. (2019). Consumer use of mobile banking (M-Banking) in Saudi Arabia: Towards an integrated model. International Journal of Information Management, 38-52.

4. Bhasin, N. K. (2007). Risk Management in Banks, Role of Information Technology. The Indian Banker, 24-33.

5. Boateng, H., Adam, D. R., Okoe, A. F., \& Anning-Dorson, T. (2016). Assessing the determinants of internet banking adoption intentions: A social cognitive theory perspective. Computers in Human Behaviour, 468-478.

6. Byers, R. E., \& Lederer, P. J. (2001). Retail bank service strategy; a model of traditional, electronic, and mixed distribution choices. Journal of Management Information Systems, 133-156.

7. C.Mathapati, A., \& Vidyavati, D. (2018). A Review of Indian Mobile Phone Sector. IOSR Journal of Business and Management (IOSR-JBM), 8-17.

8. Davis, F. D. (1989). Perceived usefulness, perceived ease of use, and user acceptance of Information Technology. MIS Quarterly, 319-340.

9. Economic Times. (2017, August 28). What percentage of Indians use online banking channels? Here's a survey estimate. Retrieved from Economic Times: https://economictimes.indiatimes.com/wealth/personal-finance-news/what-percentageof-indians-use-online-banking-channels-heres-a-surveyestimate/articleshow/60231902.cms?from $=\mathrm{mdr}$

10. Flavián, C., Torres, E., \& Guinalíu, M. (2004). Corporate Image Measurement A Further Problem For The Tangibilization Of Internet Banking Services. International, 107-125.

11. Gan, C., Clemes, M., Limsombunchai, V., \& Weng, A. (2006). A logit analysis of electronic banking in New Zealand. International Journal of Bank Marketing.

12. Giannakoudi, S. (1999). Internet banking: the digital voyage of banking and money in cyberspace. Information and Communications Technology Law, 205-243. 
13. Gounaris, S. P., \& Koritos, C. D. (2008). Using the extended innovation attributes framework and consumer personal characteristics as predictors of internet banking adoption. Journal of Financial Services Marketing volume, 39-51.

14. Hamidi, H., \& Safareeyeh, M. (2019). A model to analyze the effect of mobile banking adoption on customer interaction and satisfaction: A case study of m-banking in Iran. Telematics and Informatics, 166-181.

15. Jain, S. K., \& Gupta, G. (2004). Measuring Service Quality: SERVQUAL vs. SERVPERF Scales. VIKALP, 25-37.

16. Jani, A. S. (2012). A Study of Consumer Perception on the Use of E-Technology in the Retail Banking Sector: A Comparative Study of Public Sector and Private Sector Banks. Indian Journal of Marketing, 46-58.

17. K., M. (2010). New Technologies in Banking Sector. Banking Finance, 12-13.

18. Kaur, K., \& Rajneesh. (2014). Electronic Banking in India: Innovations, Challenges and Opportunities. International Journal of Management and Commerce Innovations, 86-93.

19. Lian, J.-W., \& Lin, T.-M. (2008). Effects of consumer characteristics on their acceptance of online shopping: Comparisons among different product types. Computers in Human Behaviour, 48-65.

20. Matos, C. A., Henrique, J. L., \& Rosa, F. d. (2013). Customer Reactions to Service Failure and Recovery in The Banking Industry: The Influence of Switching Costs. Journal of Services Marketing, 526-538.

21. Mohamed Merhia, K. H. (2019). A cross-cultural study of the intention to use mobile banking between Lebanese and British consumers: Extending UTAUT2 with security, privacy and trust. Technology in Society, 1-12.

22. Nupur, J. M. (2010). E-Banking and Customers' Satisfaction in Bangladesh: An Analysis. International Review of Business Research Papers, 145-156.

23. Paul, N., \& Richmond, W. (2007). Internet Banking: Gold Mine or Money Pit? . Academy of Banking Studies Journal, 1-25.

24. Philip Avornyoa, J. F. (2019). Are customers still with us? The influence of optimum stimulation level and IT-specific traits on mobile banking discontinuous usage intentions. Journal of Retailing and Consumer Services, 348-360.

25. S.Suriyamurthi, Mahalakshmi, V., \& Arivazhagan, M. (2013). Global Banking Survey: A New Era of Customer Satisfaction with reference to India. African Journal of Business Management, 125-134.

26. Saha, P., \& Zhao, Y. (2005). Relationship between Online Service Quality and Customer Satisfaction: A Study in Internet Banking. Sweden: Master Thesis, Luleå University of Technology.

27. Srivastava, D. S. (n.d.). Internet Banking - A Global Way to Bank! Retrieved from www.indianmba.com/Faculty_Column/FC908/fc908.html 
28. Statista Research Department. (2020, January 17). Internet usage in India - Statistics \& Facts . Retrieved from Statista: https://www.statista.com/topics/2157/internet-usage-inindia/

29. Tina, C. Y. (2003). Dynamics of Banking Technology Adoption: An Application to Internet Banking. Warwick Economics Research Papers, University of Warwick, UK.

30. Ülengin, B. (1998). Using hierarchical information integration to examine customer preferences in banking. International Journal of Bank Marketing, 202-210.

31. Vanniarajan, D. T., \& Anbazhagan, B. (2007). SERVPERF: Analysis in Retail Banking. International Marketing Conference on Marketing \& Society, (pp. 725-736). Kozhikode: IIMK.

32. Venkatesh, V. e., Morris, M. G., Davis, G. B., \& Davis, F. D. (2003). USER ACCEPTANCE OF INFORMATIONTECHNOLOGY:TOWARD A UNIFIED VIEW. MIS Quarterly, 425-478.

33. Venkatesh, V., \& Davis, F. D. (2000). A Theoretical Extension of the Technology Acceptance Model: Four Longitudinal Field Studies. Management Science, 186-204.

34. Venkatesh, V., Thong, J. Y., \& Xu, X. (2012). Consumer Acceptance and Use of Information Technology: Extending the Unified Theoryof Acceptance and Use of Technology. MIS Quarterly, 157-178.

35. Waranpong Boonsiritomachai, K. P. (2017). Determinants affecting mobile banking adoption by generation $\mathrm{Y}$ based on the Unified Theory of Acceptance and Use of Technology Model modified by the Technology Acceptance Model Concept. Kasetsart Journal of Social Sciences, 1-10.

36. Yoon, \& Cheolho. (2010). Antecedents of customer satisfaction with online banking in China: The effects of experience. Computers in Human Behavior, 1296-1304. 


\section{Appendix}

Appendix I: Histogram chart of public and private sector banks
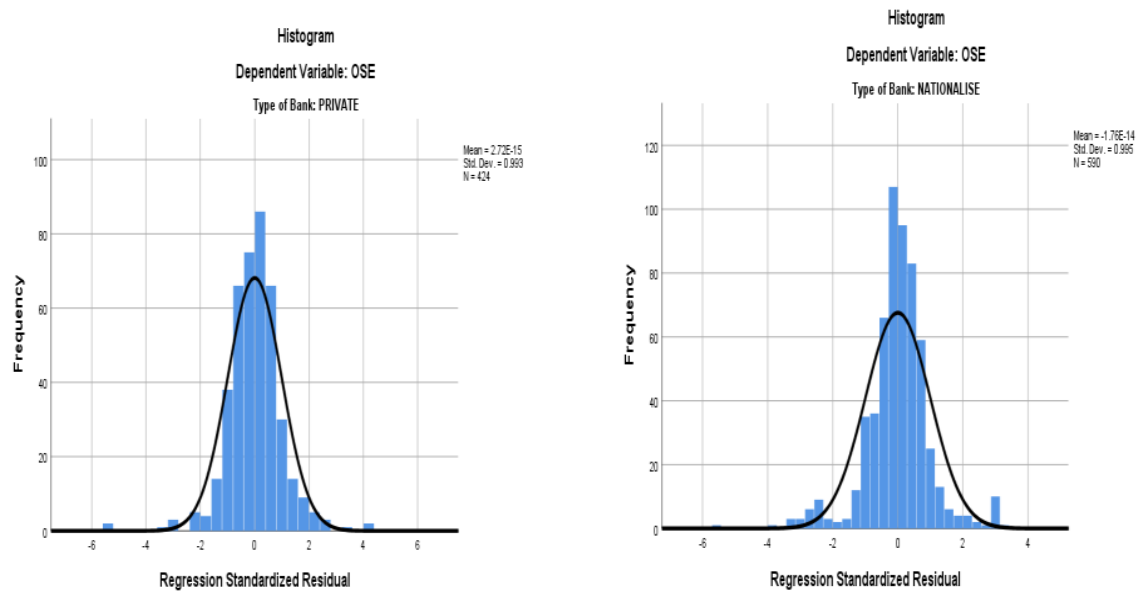

Appendix II: Normal P-P plot of regression standardized value chart of public and private sector banks
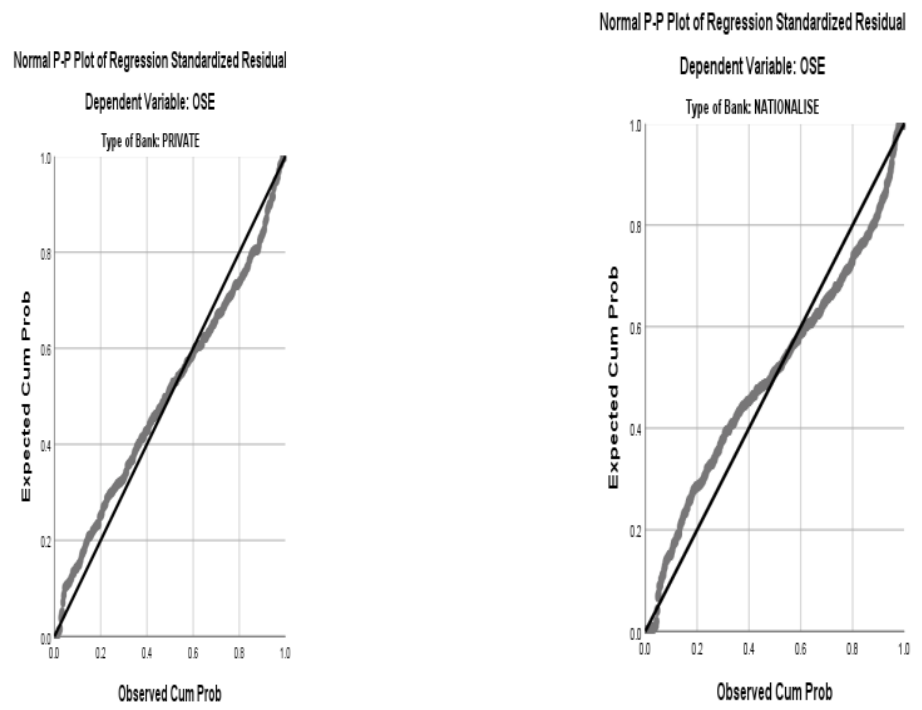
Appendix III: Scatterplot chart of public and private sector banks
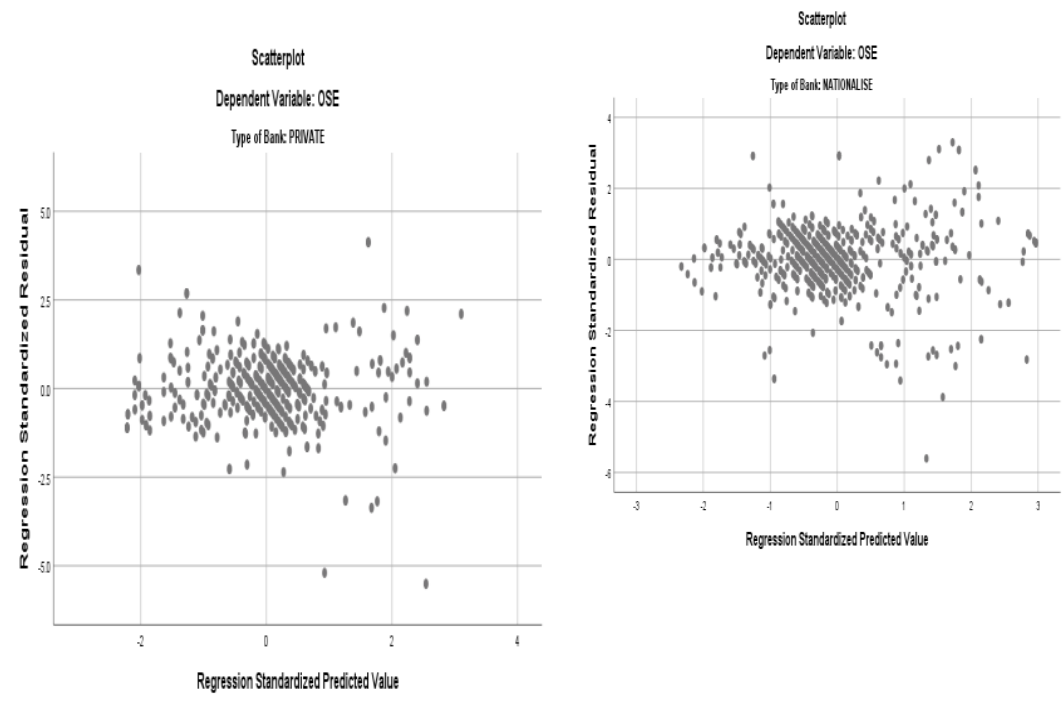